\title{
UM ESTUDO CRÍTICO DO LIVRO CHAPEUZINHO AMARELO DE CHICO BUARQUE
}

\author{
Moysa Yoshimura da Cruz (G-UEMS) \\ Washington Cesar Shoiti Nozu (G-UEMS) \\ Estela Natalina Mantovani Bertoletti (UEMS)
}

\section{Resumo}

Acompanhando o processo de delineamento do conceito de infância (século XVIII), surge um gênero literário voltado à especificidade das crianças: a literatura infantil. No Brasil, tornou-se consensual afirmar que a produção de uma literatura adequada aos pequenos inicia-se em 1921, com a publicação de A menina do narizinho arrebitado, de Monteiro Lobato. É comum afirmar, também, que a diversificação da produção literária voltada para as crianças e o aparecimento de novos autores tomou grandes proporções a partir de 1970 - contexto em que surge, em 1979, o livro Chapeuzinho Amarelo, de Chico Buarque, mote do estudo em questão. Contudo, apesar de sua relevância para a formação humana, a literatura infantil ainda é, equivocadamente, tida por muitos como um gênero menor, quer pelo público a que se destina quer pela insistência de uma pedagogia utilitarista. Nesse sentido, sem a pretensão de esgotar o tema, o presente trabalho tem o intuito de analisar o livro Chapeuzinho amarelo, a partir do exame de seus aspectos textuais, gráficos e intertextuais, com o fito de superar ideias que, por vezes, inferiorizam o gênero ao qual o livro está inserido. Trata-se de uma pesquisa bibliográfica que seguiu, preponderantemente, a dedução como método de raciocínio para obter os resultados objetivados. Em suma, por meio de um olhar mais reflexivo, pode-se afirmar que o livro sob análise - publicado pela Berlendis e Vertecchia Editores Ltda constitui-se, muito mais que uma paráfrase do livro Chapeuzinho vermelho, de Charles Perrault, em excelente instrumento para a compreensão da leitura enquanto prática social.

Palavras-chave: Literatura infantil. Gênero literário. Chapeuzinho Amarelo.

\section{Introdução}

De acordo com Zilberman (2003), a partir do século XVIII, iniciou-se o delineamento do conceito de infância, passando a considerar os aspectos físicos e mentais dos seres nesta fase da vida humana. Até então, as crianças eram tidas como "adultos em miniaturas", não recebendo os cuidados atinentes à infância (ARIÈS, 1978).

Acompanhando esse processo que entendia a criança como um ser com características e necessidades próprias, originou-se também um gênero literário voltado à sua especificidade: a literatura infantil.

Assim, na busca de uma literatura também adequada à criança, passou-se a fazer adaptações dos grandes clássicos lidos pela nobreza européia e a apropriação do folclore pelos contos de fada. Conforme Cunha (2003, p. 23), "Perrault e depois os irmãos Grimm, colecionadores dessas histórias folclóricas, estão assim ligados à gênese da literatura infantil”" 
No Brasil, no primeiro decênio do século XX, a origem da literatura infantil estava ligada, basicamente, à escola, que utilizava adaptações de produções portuguesas. Com propriedade, Cunha (2003, p. 23-24) elucida que

Essa fase embrionária da literatura infantil brasileira é representada em especial por Carlos Jansen (Contos seletos das mil e uma noites, Robinson Crusoé, As viagens de Gulliver a terras desconhecidas), Figueiredo Pimentel (Contos da carochinha), Coelho Neto e Olavo Bilac (Contos pátrios) e Tales de Andrade (Saudade).

É consensual, contudo, que com Monteiro Lobato inicia-se uma produção de literatura infantil brasileira, mais elaborada, com a publicação do livro A menina do narizinho arrebitado, em 1921. Lobato, ao contrário de muitos, enxergava a criança como um ser perspicaz, capaz de compreender assuntos antes dirigidos somente aos adultos, como a guerra, a política, o petróleo, estimulando nos pequenos uma consciência crítica a partir da realidade apresentada. Ademais, Lobato unia de maneira harmoniosa o real e o mágico, escrevendo histórias fantásticas que faziam dos seus livros "um lugar para se morar".

Depois de Lobato, de acordo com Sandroni (1998, p. 17)

\begin{abstract}
Destacam-se alguns autores que souberam manter sua originalidade e escreveram livros que, até hoje, permanecem nos catálogos das editoras enquanto os demais foram rapidamente esquecidos. Entre os primeiros não podemos deixar de citar Menotti Del Picchia, Malba Tahan, José Lins do Rego, Viriato Correia, Érico Veríssimo, Vicente Guimarães, Ofélia e Narbal Fontes, Francisco Marins, Orígenes Lessa, Lúcia Machado de Almeida e Maria José Dupré que, em maior ou menor grau, realizaram obras nas quais o imaginário e o lúdico encontraram uma linguagem adequada para expressar-se, abordando temas históricos ou de inspiração folclórica ou ainda criando aventuras maravilhosas.
\end{abstract}

A partir da década de 1970 - tida como o "boom" da literatura infantil no Brasil, a produção literária voltada para as crianças tomou grandes proporções, com grande diversificação e aparecimento de novos autores, como Ruth Rocha, Ana Maria Machado, Lygia Bojunga Nunes, Mário Quintana, Sidônio Muralha, entre outros. Muitos desses autores foram fortemente influenciados por Lobato (SANDRONI, 1998), utilizando o humor, a ironia, a crítica social, o folclore, a linguagem coloquial, fato que possibilitou, em suas obras, um "abrasileiramento" da literatura infantil. A literatura abandona o esteticismo existencialista dos anos 50, a rigidez ideológico-
pedagógica dos anos 60 , vale-se da ironia e da fantasia para driblar a censura dos
anos 70 e, finalmente nos anos 80 , lança-se à apropriação dos meios da cultura de
massa, então já garantida pelo agigantamento das redes de televisão, parodiando-os.
(BORDINI, 1998, p. 36).

É nesse contexto de diversificação e efervescência da literatura infantil brasileira que surge, em 1979, o livro Chapeuzinho amarelo, de Chico Buarque, alvo do estudo em questão. 
Nesse sentido, após o esboço histórico da gênese até o advento do "boom" da literatura infantil na década de 1970, no Brasil, o presente trabalho - resultado de leituras, discussões e reflexões advindas das aulas de Linguagem e Literatura Infantil, no ano de 2007, no Curso de Pedagogia, da Universidade Estadual de Mato Grosso do Sul, Unidade Universitária de Paranaíba - tem o intuito de analisar o livro Chapeuzinho amarelo, a partir do exame de seus aspectos textuais, gráficos e intertextuais, com o fito de superar ideias menos esclarecidas que, por vezes, inferiorizam o gênero no qual o livro está inserido.

Assim, a princípio, far-se-á um breve levantamento a respeito da vida e da obra do autor do livro, na tentativa de realizar uma leitura crítica do texto e, desse modo, compreender por que e para quê Chapeuzinho amarelo foi escrito. Em seguida, pretende-se analisar, minuciosamente, os aspectos textuais e gráficos do livro. Por fim, pretende-se interpretar os aspectos intertextuais do livro sob análise, relacionando-os a vida e obra do autor, ao conceito de literatura infantil presente no livro e, ainda, ao conto Chapeuzinho vermelho, dos Irmãos Grimm.

\section{Da Vida e Obra do Autor ${ }^{1}$}

Francisco Buarque de Holanda, filho do renomado historiador Sérgio Buarque de Holanda e de Maria Amélia Cesário Alvim, nasceu no Rio de Janeiro, em 19 de junho de 1944.

Desde criança, Chico sentia-se atraído pela música. Aos quinze anos, estreia num show de estudantes com a música de sua autoria Marcha para um dia de sol.

De ouvidos atentos, Chico deixou-se levar pela voz e a bossa nova de João Gilberto na composição de Tom Jobim e Vinicius de Moraes, situação que influenciaria os rumos de sua vida artística.

Chegou à vida universitária no início da década de 1960, auge do movimento popular e estudantil que precedeu o golpe militar de 1964. Em 1965, reunindo poesia ao futebol, feijoada à música, a solidariedade ao bom humor, Chico escreve os sessenta versos de Pedro

\footnotetext{
${ }^{1}$ Informações sobre a vida e obra de Chico Buarque obtidas nos sites: BIOGRAFIAS. Chico Buarque de Holanda. Disponível em: <http://www.e-biografias.net/biografias/chico_buarque.php>. Acesso em: 25 maio 2009.

NETSABER BIOGRAFIAS. Chico Buarque de Holanda. Disponível em: <http://www.netsaber.com.br/biografias/ver_biografia_c_494.html>. Acesso em: 25 maio 2009. WIKIPÉDIA. Chico Buarque. Disponível em <http://pt.wikipedia.org/wiki/Chico_Buarque>. Acesso em: 25 maio 2009.
} 
pedreiro e, também no mesmo ano, é convidado por Roberto Freire a musicar Morte e vida severina, de João Cabral de Mello Neto.

Apesar de o Brasil já estar sob as botas da ditadura, a televisão era ainda incipiente e a juventude da época respirava música, teatro, literatura e cinema brasileiros. Em 1966, A banda ganha o II Festival de Música Popular Brasileira da TV Record. No mesmo ano, Chico grava seu primeiro LP e se torna uma celebridade nacional e internacional.

Aos poucos, o regime endurecia e forçava aqueles que participavam do mundo da produção cultural, catalisadores do pensamento nacional, a tomar posições. Em 1967, as ruas brasileiras começaram a sentir o estremecimento provocado pelos tanques e pelas botinas dos militares no poder. No ano de 1968, Chico Buarque escreve a peça teatral Roda viva, que desafiou a repressão que o país sofria e obteve plausível sucesso no meio cultural paulista.

Quando o Ato Institucional no 5, de 13 de dezembro de 1968, "explodiu”, a vida de Chico tornou-se conturbada, sendo, inclusive, no dia 18 do mesmo mês, acordado com os militares já forçando a porta de seu apartamento. Assim, reprimido, no dia 03 de janeiro de 1969, ele e sua então esposa, Marieta Severo, embarcaram para Cannes, na França. Exilados, a primeira filha do casal, Silvia, acabou nascendo na Itália, em 28 de março de 1969.

Mesmo estando a ditadura sob o poder do general mais linha dura, Emílio Garrastazu Médici, que num discurso político do "pão e circo" fomentava o slogan "Brasil: ame-o ou deixe-o", Chico e a família retornam, no início de 1970, ao Brasil.

Em 1971, lançou Construção, dando tons concretos à realidade dura dos brasileiros das classes mais populares, flagrando a impossibilidade de ação diante das grandes estruturas de poder que se formavam no começo dos anos 1970. Chico mostrou os tons obscuros da política militar do "pão e circo", que buscava a alienação das massas, sob o manto do patriotismo exacerbado.

Tendo se transformado num símbolo de luta contra a ditadura, Chico, com o intuito de escapar da censura, criou o pseudônimo Julinho da Adelaide. Julinho compôs três músicas: Acorda amor, Jorge Maravilha e Milagre brasileiro.

Em 1974, escreveu sua primeira obra literária, Fazenda modelo, baseado no livro $A$ revolução dos bichos, de George Orwell, e, em 1977, lança seu primeiro disco para crianças, intitulado Saltimbancos, baseado no conto Os músicos de Bremen, dos Irmãos Grimm.

No fim da década de 1970, a crise do petróleo fez cair por terra as ilusões do milagre brasileiro sustentadas pelo governo militar. Assim, a ditadura perdia a única justificativa 
possível: o crescimento econômico. Os generais preparavam sua saída e anunciavam a anistia aos exilados.

Foi nesse processo inicial de redemocratização que Chico Buarque estreia na área da literatura infantil e lança, em 1979, o livro Chapeuzinho amarelo.

\section{Da Análise dos Aspectos Textuais e Gráficos}

Chapeuzinho amarelo - livro que inseriu Chico Buarque no campo de literatura infantil - foi publicado, inicialmente, pela Berlendis \& Vertecchia Editores Ltda, com o planejamento gráfico realizado por Donatella Berlendis. Posteriormente, a editora José Olympio publicou Chapeuzinho amarelo, ilustrado por Ziraldo. Por razões históricas, neste texto, a análise dos aspectos gráficos e textuais percorrerá as páginas da publicação feita pela editora Berlendis \& Vertecchia.

Chapeuzinho amarelo é um clássico da literatura infantil brasileira, sendo considerado “altamente recomendado" pela Fundação Nacional do Livro em 1979. O livro conta as aventuras, de forma linear e bem humorada, de uma menina que tinha medo de tudo. E de todos os medos que ela tinha, o maior era o de um dia encontrar "o tal do lobo". Mas, quando Chapeuzinho amarelo encontrou o lobo, o seu medo foi passando de tal forma que o algoz acabou virando um "bolo".

A capa do livro, autenticada com selo de "Obra selecionada para o Programa Nacional Salas de Leitura/Bibliotecas Escolares" - MEC/FAE, é ilustrada com dois grandes olhos negros, com expressão de medo, e um chapéu de aba amarela que desperta no leitor a ideia de que a menina está se escondendo de algo.

Logo ao abrir o livro, Chico diz que "A historinha foi feita para Luisa. O livro é dela, da Silvia, da Helena, da Janaína, da Alaíde, da Luiza, do Antônio e de outros”. E, na sequência, inicia a narração:

Era a Chapeuzinho Amarelo.

Amarelada de medo.

Tinha medo de tudo, aquela Chapeuzinho.

Já não ria.

Em festa, não aparecia.

Não subia escada

nem descia.

Não estava resfriada

mas tossia.

Ouvia conto de fada

e estremecia. 
Não brincava mais de nada,

nem de amarelinha.

Nesse texto, o autor apresenta a personagem, caracterizada essencialmente pelo medo (“Amarelada de medo") definido, sobremaneira, pelos verbos ("Tinha medo de tudo, aquela Chapeuzinho"; "Ouvia conto de fada e estremecia”), ou na negação destes (“Já não ria"; "Em festa, não aparecia"; "Não subia escada nem descia"; "Não estava resfriada mas tossia"; "Não brincava mais de nada, nem de amarelinha"). Cabe observar o jogo de palavras envolvendo o amarelo. Conforme Cunha (2003, p. 89), “[...] o amarelo sugere-nos o desagradável; falamos por exemplo, em 'sorriso amarelo' (de desconforto), em pessoa amarelo (de susto, de anemia)". A ilustração destes versos mostra o rosto de uma menina receosa, em que o amarelo do chapéu transfere-se para as suas faces.

Em seguida, a história mostra que o medo de tudo não deixava a menina fazer nada:

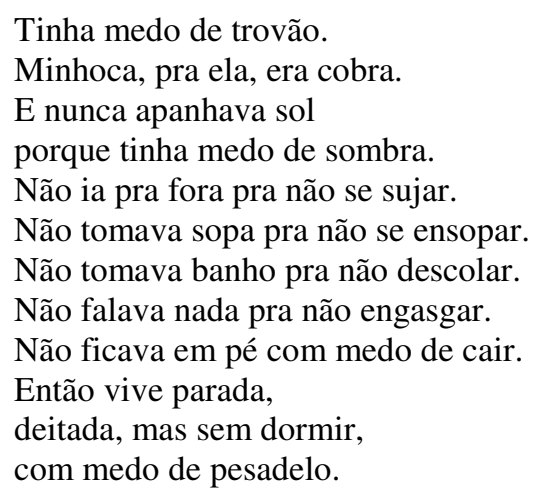

O narrador, assim, descreve a atitude de uma criança que transforma a fantasia dos contos em sua própria realidade, chegando ao ponto de não brincar, não se divertir, não comer, nem dormir. Salienta-se que o medo da menina era tamanho que a impedia de ser consciente. A ilustração reforça essa ideia, mostrando Chapeuzinho encolhida num pequeno canto da página, ocupando o menor lugar possível, enquanto do outro lado da página, três meninas (apresentadas apenas em contornos) brincam de roda, descontraídas.

$\mathrm{Na}$ página seguinte, aparece novamente a frase "Era a Chapeuzinho Amarelo", em letras maiores que ocupam toda uma página, na intenção de encerrar esse primeiro momento de apresentação da personagem. A imagem ilustrativa é a mesma que aparece na capa, ou seja, a parte de um rosto, dominado por grandes olhos negros espantados.

Na sequência, inicia-se um segundo momento, em que aparece a sugestão de um lobo, que era o "medo mais que medonho" da Chapeuzinho Amarelo:

\footnotetext{
E de todos os medos que tinha

o medo mais que medonho

era o medo do tal do LOBO.
} 


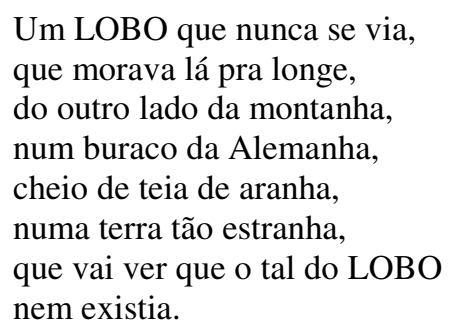

O lobo era o maior medo da Chapeuzinho, mesmo aparecendo, inicialmente, como um fruto de sua imaginação. Um lobo que, de tão longe que morava - como o "outro lado da montanha", "num buraco da Alemanha", "numa terra tão estranha" -, talvez nem existisse. Uma teia de aranha, sugerindo o lugar onde o lobo poderia morar, ilustra o texto.

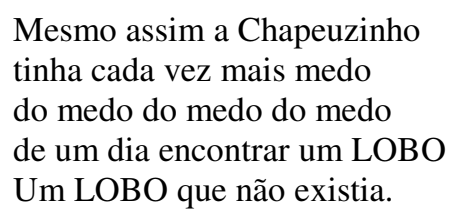

No texto acima, Chico Buarque utiliza-se da repetição do substantivo medo para demonstrar a intensidade de temor que o lobo causava na menina. A frase: "Um LOBO que não existia”, já explicitado em verso similar anteriormente, reitera a noção de que o lobo não é senão um produto do pensamento temeroso da Chapeuzinho. A ilustração correspondente a esse trecho é representada por uma perna da menina, que, numa passada larga, sugere um movimento de fuga. Ainda, a sombra projetada das suas pernas tendenciona o formato da boca de um lobo - e essa boca representa o medo que a menina possuía de um lobo nãoexistente e só aparece como uma sombra recortada na claridade.

Acontece que:

$$
\begin{aligned}
& \text { E Chapeuzinho Amarelo, } \\
& \text { de tanto pensar no LOBO, } \\
& \text { de tanto sonhar com o LOBO, } \\
& \text { de tanto esperar o LOBO, } \\
& \text { um dia topou com ele } \\
& \text { que era assim: } \\
& \text { carão de LOBO, } \\
& \text { olhão de LOBO, } \\
& \text { jeitão de LOBO } \\
& \text { e principalmente um bocão } \\
& \text { tão grande que era capaz } \\
& \text { de comer duas avós, } \\
& \text { um caçador, rei, princesa, } \\
& \text { sete panelas de arroz } \\
& \text { e um chapéu de sobremesa. }
\end{aligned}
$$

Finalmente, a Chapeuzinho, ao alimentar o medo "mais que medonho" do lobo, um dia o encontrou (ilustrado na página com um contorno de "carão" malicioso). 
Tal lobo, por ter uma boca tão grande, "era capaz de comer duas avós, um caçador, rei, princesa, sete panelas de arroz e um chapéu de sobremesa”. Sobre essa passagem, esclarece Cunha (2003, p. 92) que

[...] a enumeração do que o lobo é capaz de comer é, por si, exagerada - o que nos faz desconfiar de sua veracidade e do real perigo do lobo. Além do exagero, a enumeração mistura elementos imprevisíveis. Aparecem (aumentados ou em situação inversa) elementos da história de Chapeuzinho Vermelho, como duas avós, o caçador (aqui caçado), rei e princesa (dos contos de fadas), ao lado da trivialidade de "sete panelas de arroz" e um chapéu, de sobremesa. Observe-se o uso do sete, número 'mágico', que aparece com frequencia nos relatos infantis ou bíblicos, e que reforça aqui a 'conta de mentiroso' - o exagero na descrição da periculosidade do lobo. E o chapéu tem duplo sentido: pode ser o objeto que se usa na cabeça (comido pelo lobo, por seu mau gosto e apetite), como pode ser a Chapeuzinho.

Antes de se encontrar com o lobo, Chapeuzinho tinha pavores só de pensar nele,

\author{
Mas o engraçado é que, \\ assim que encontrou o LOBO, \\ a Chapeuzinho Amarelo \\ foi perdendo aquele medo, \\ o medo do medo do medo \\ de um dia encontrar um LOBO. \\ Foi passando aquele medo \\ do medo que tinha do LOBO. \\ Foi ficando só com um pouco \\ de medo daquele lobo. \\ Depois acabou o medo \\ e ela ficou só com o lobo.
}

Assim, a partir deste encontro, Chapeuzinho, que se fechava para o mundo, presa à sua imaginação, começa a enxergar o lobo como um animal qualquer, provavelmente incapaz de devorar pessoas. Salienta-se que a repetição do substantivo medo, utilizado anteriormente para ressaltar a intensidade de pavor, vai se degradando ("o medo do medo do medo"; "Foi passando aquele medo do medo que tinha do lobo"; "Foi ficando só com um pouco de medo daquele lobo") até ser eliminado da frase ("Depois acabou com o medo e ela ficou só com o lobo”). Conforme Cunha (2003, p. 92), “[...] a palavra LOBO, que aparecia em letras grandes, acaba por ter a dimensão das outras palavras: tornou-se comum". Além disso, atente-se para a ambiguidade do último verso que dá a entender que a Chapeuzinho ficou sem o medo do lobo, e/ou que ela ficou sozinha com ele. A ilustração mostra o rosto da menina mais sereno, com o amarelo do chapéu transferido para suas bochechas.

Em seguida, percebendo que já não é visto como malvado, o lobo fica chateado e envergonhado, sem a função de amedrontar crianças.

\footnotetext{
O lobo ficou chateado de ver aquela menina olhando pra cara dele, só que sem o medo dele.
} 
Ficou mesmo envergonhado, triste, murcho e branco azedo, porque um lobo, tirado o medo, é um arremedo de lobo.

É feito um lobo sem pelo.

Lobo pelado.

O lobo "tirado o medo" passa a ser "um arremedo de lobo", um animal descaracterizado que, desmascarado o medo, realmente não existe. A ilustração desses versos mostra o contorno de um animal (o lobo), sem a cabeça e com o rabo entre as pernas.

A frase "O lobo ficou chateado" ocupa, em letras grandes, a página dupla seguinte, sintetizando o sentimento despertado no lobo ao perceber que não amedontrava mais a Chapeuzinho. Ademais, a frase-síntese encerra o segundo movimento da narrativa.

Não se contentando em ser descaracterizado, o lobo tenta restabelecer a ordem:

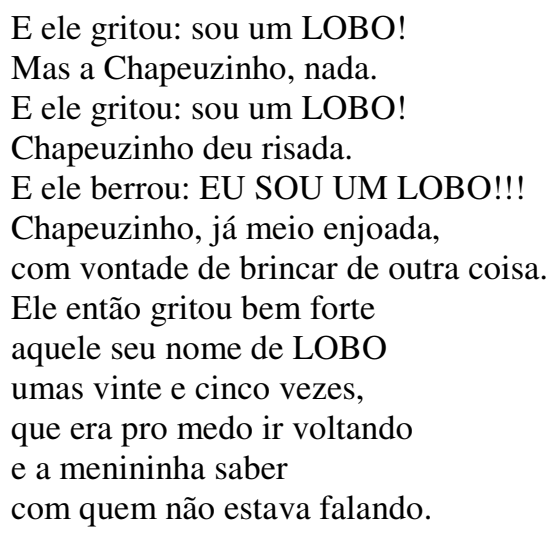

Revoltado, o lobo grita e berra seu nome várias vezes querendo reafirmar seu status. Em contrapartida, Chapeuzinho deu risada e foi se enjoando daquela gritaria e "ficando com vontade de brincar de outra coisa".

Com propriedade, afirma Cunha (2003, p. 93) que

\begin{abstract}
Vemos aí novamente o exagero que desmoraliza e um caso interessante de clichê modificado: a expressão 'com quem não estava falando', sem a negativa, é um chavão usado para sugerir que estamos falando inadequadamente com alguém importante. É sempre uma ameaça. Aqui, a negativa torna o lobo ridículo.
\end{abstract}

A ilustração correspondente mostra o contorno de uma Chapeuzinho renovada, descontraída, que não leva o chapéu na cabeça, mas o segura na mão esquerda, enquanto brinca de amarelinha.

E o lobo continua tentando se reafirmar na página dupla seguinte: "LO-BO-LO-BOLO-BO-LO-BO-LO-BO-LO-BO-LO-BO-LO-BO-LO-BO-LO-BO-LO”. Nestas páginas que representam o lobo gritando, há uma junção entre signos verbais, sonoros e visuais, compondo um todo significativo. Escrito em letras maiúsculas, o nome "LOBO" já nos dá a 
ideia de sujeito poderoso, maior que os demais - isto é, o próprio signo verbal mostra-se como imagem.

Contudo, a desagradável repetição "LO-BO-LO-BO-LO” é interrompida pela menina:

\author{
Aí Chapeuzinho encheu e disse: \\ "Pára assim! Agora! Já! \\ Do jeito que você tá!" \\ E o lobo parado assim \\ do jeito que o lobo estava \\ já não era um LO-BO. \\ Era um BO-LO. \\ Um bolo lobo fofo, \\ tremendo que nem pudim, \\ com medo da Chapeuzim. \\ Com medo de ser comido, \\ com vela e tudo, inteirim.
}

Parado, do jeito que estava, o lobo ("LO-BO-LO-BO-LO”) virou bolo, por meio da semelhança de sílabas e de alternâncias da palavra repetida na folha. O narrador, nessas frases inverte os papeis: agora era o lobo que estava morrendo de medo de ser comido "inteirim" pela "Chapeuzim". Note-se que as palavras "Chapeuzim" e "inteirim" foram escritas com o propósito de dar um efeito sonoro ao poema, quando da rima com a palavra pudim.

Contudo, a menina não gostava de bolo de lobo, desse modo:

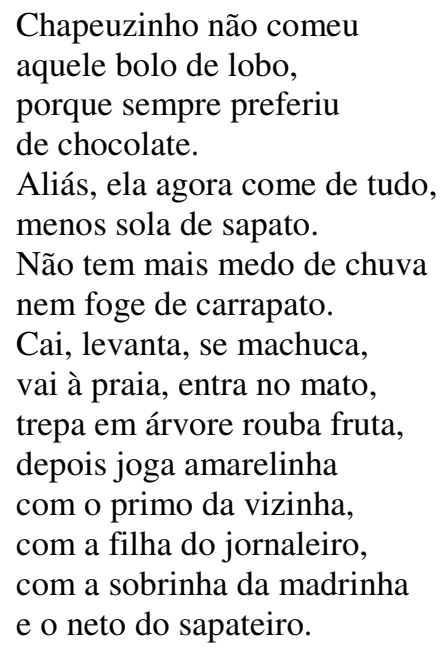

A narrativa faz uso do humor, ao dizer que "Chapeuzinho não comeu aquele bolo de lobo, porque sempre preferiu de chocolate". Nesse momento, o lobo, que virou bolo, desaparece da história e Chapeuzinho aparece com uma nova apresentação: come de tudo, vai à praia, entra no mato, joga amarelinha. De acordo com Cunha (2003, p. 94), “[...] as orações, antes na forma negativa, tornam-se afirmativas, e formam um longo período de orações coordenadas, sugerindo o dinamismo atual da menina. O último verbo que aparece com negação é exatamente aquele que antes vinha na afirmativa: ter medo (e fugir)”.

\begin{tabular}{|l|l|l|l|l|l|}
\hline Interface da Educ. & Paranaíba & v. 1 & n. 1 & p. 95-110 & 2010 \\
\hline
\end{tabular}


Note-se que o texto não se atenta à separação de sexo e de classe social, ao dizer que a menina "joga amarelinha com o primo da vizinha, com a filha do jornaleiro, com a sobrinha da madrinha e o neto do sapateiro". A ilustração mostra uma mão (provavelmente da Chapeuzinho) apanhando uma maçã bem vermelha no alto de uma árvore (macieira) muito verde.

Nos últimos versos, Chapeuzinho cria um mecanismo para superar os seus medos.

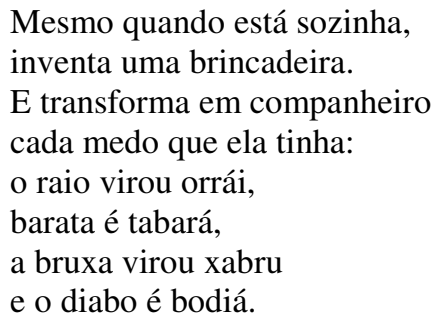

Assim como o lobo virou bolo quando a menina o encontrou, agora, à base de trocadilhos e deslocamentos entre palavra-som-imagem, ela brinca com os medos que tinha, transformando-os em companheiros - o velho em novo. $\mathrm{Na}$ ilustração, a menina diferentemente das outras imagens, aparece sem o chapéu, sorrindo e com as bochechas vermelhas como a maçã da ilustração anterior.

A palavra FIM que segue os últimos versos é um despiste. Ao virar a página, o autor sugere, por meio de uma interjeição, algo que deixou de contar; "Ah, outros companheiros da Chapeuzinho Amarelo: O Gãodra, a Jacoru, o Barão-Tu, o Pão Bichôpa e todos os trosmons”. E, ao brincar com as palavras novamente, virando-as pelo avesso, a menina torna-se íntima de cada medo que ela sentia. A ilustração da página sugere contornos de uma coruja, de um "bicho-papão", de um jacaré, de um sapo e de um hipopótamo com feições amigáveis.

A história acabou? Ainda não! Na próxima página, aparece o chapéu amarelo da menina ao alto, como se jogado para o ar. A ilustração confirma que, ao superar todos os seus medos, o chapéu da menina, símbolo da defesa, tornou-se inútil.

Por fim, cabe salientar que Donatella Berlendis, na associação palavra-imagem, superou um estilo convencional de ilustração: mesmo sem muitas imagens e cores, as ilustrações expressam o impacto e o humor que o texto pretende. Trabalhou com índices ou pistas dadas para o leitor-criança que irá preencher e/ou completar as partes das ilustrações que não vê na página, com base na leitura verbal. Neste trabalho da artista com o poeta, a ilustração integra-se à palavra e mesmo a amplia com sugestões de imagens.

Este livro exemplifica que não é necessário que a obra de literatura infantil seja redundante e fechada, pelos simples fato de ser feita para crianças, sugerindo que, por meio

n. 1 p. $95-110$ 
do conhecimento de mundo que já possuem, os pequenos leitores consigam conectar pistas dadas pela palavra, pelo som e pela imagem, unindo signos e fragmentos aos sentidos não explícitos no texto.

\section{Dos Aspectos Intertextuais}

Todo escritor deve ser visto como um reflexo produzido por uma sociedade em determinado lapso de tempo. Assim, com o fito de realizar leitura crítica do livro, não se pode desconsiderar a época em que Chico Buarque escreveu Chapeuzinho amarelo.

A década de 1970 é tida como o grande "boom" da literatura infantil brasileira, devido à diversificação da produção e publicação e ao surgimento de autores antes desconhecidos. Contudo, é nos anos 80 que a literatura infantil começa a consolidar-se, ganhando corpo de uma produção cultural refletida.

Conforme ensina Bordini (1998, p. 44),

Solidificando-se, nos anos 80, a partir do novo processo de modernização da sociedade, com sua débil redemocratização e contínuas tentativas de chegar a uma economia de escala, sem inflação e com a aspiração de garantir o bem-estar social a setores mais amplos da sociedade, a literatura infantil brasileira definiu seu próprio sistema de produção e de circulação de bens culturais, a partir da demanda de um público cativo - o escolar - e do estímulo estatal à empresa privada.

Salienta-se que Chapeuzinho amarelo, publicado em 1979, aparece como uma balança entre as décadas de 1970 e 1980 - período em que os militares se encontravam no poder no Brasil. Outrossim, não seria difícil que Chico Buarque - uma das bandeiras na luta contra a ditadura - utilizasse a literatura infantil para criticar, sutilmente, a situação de opressão vivida pelos brasileiros.

Assim, de um lado, pode-se comparar a figura inicial de uma menina oprimida ("Amarelada de medo") que tinha o "medo mais que medonho" de um dia encontrar o lobo. Um lobo que ao perceber que não era respeitado, gritou "umas vinte e cinco vezes" para tentar se impor. Nesse plano metafórico, é possível aproximar a figura do lobo aos generais da ditadura militar que pisavam forte no começo dos anos de 1970, reprimindo e censurando as manifestações de liberdade e pensamento (transfigurados na pele da menina Chapeuzinho). Note-se que o número de vezes que o lobo gritou seu nome (vinte e cinco), pode sugerir a previsão de anos que Chico Buarque acreditava durar o período militar, iniciado com o golpe de 1964. 
Entretanto, na sequência, a menina foi perdendo o medo do lobo, que, numa brincadeira, acabou virando um bolo. Nesse sentido, podemos visualizar o processo de redemocratização no Brasil (final da década de 1970 e início da década de 1980), em que os cidadãos (Chapeuzinho) começaram a protestar contra a opressão da ditadura (todos os medos da menina).

Acerca da influência desse período na produção literária infantil, pontua Bordini (1998, p. 40) que

Se ao fim dos anos 70 a tendência dominante no gênero era a contestatória, expressando as insatisfações populares e humanistas com os resultados da política desenvolvimentista do regime militar, nos anos 80 , mais liberalizados, tudo podia ser matéria para ficção infanto-juvenil.

Mesmo se interpretado na condição crítica à ditadura, não se pode negar o caráter essencialmente infantil presente no livro, que, inclusive, foi dedicado às filhas pequenas do autor. Isso porque Chapeuzinho amarelo prima, ao contrário de outras obras mais ligadas à pedagogia do que à arte, pelo imaginário da criança, num contexto verossímil que se preocupa com a realidade, mas não com a verdade.

Essa linguagem artística, humana, presente em Chapeuzinho amarelo, busca sugerir ideias e experiências, num jogo em que as palavras, os sons e as imagens se cruzam e constroem uma leitura poética, plena de descobertas, suscitando um debate de que nem sempre será necessária a redundância verbo-visual para a compreensão do texto pelos pequenos leitores.

De todo modo, o livro de Chico Buarque, por meio do próprio título, traz a marca da relação intertextual com conto tradicional Chapeuzinho vermelho, que foi retirado do folclore europeu pelo francês Charles Perrault e, posteriormente, em versão dos irmãos alemães Grimm.

Chapeuzinho vermelho conta a história de uma menina que, por não observar os conselhos da mãe (para não demorar pelo bosque e não se desviar do caminho), acaba sendo engolida por um lobo. De acordo com Cunha (2003, p. 95), “[...] em Chapeuzinho Vermelho, a menina é comida (ou quase, conforme versão) pelo lobo, porque desobedeceu à mãe. Castigada com a morte ou um grande susto, perceberá que deve ouvir os mais velhos; quando salva, um adulto, o caçador, é que irá redimi-la”.

A partir daí, Chico Buarque, ao escrever Chapeuzinho amarelo, satiriza o medo milenar à proibição que, ao ser transgredida por Chapeuzinho vermelho, precisa ser punida (devorada pelo lobo) como um exemplo a não ser seguido.

Interface da Educ. v. 1

Paranaíba
n. 1

n. 1

p. $95-110$


Nas palavras de Coelho (1995, p. 211-212),

É essa, a nosso ver, a mais importante mensagem transmitida por esta nova Chapeuzinho Amarelo. Até que ponto as leis, códigos, costumes ou interdições, institucionalizados ou não, que nos regem, são válidos? Até que ponto o medo deve continuar sendo a única reação possível diante do interdito injusto e arbitrário? Novos tempos já se desenham no horizonte e a literatura (ou a arte em geral) já está podendo rir dos 'monstros'. E não há 'fantasma' que resista a boas gargalhadas. A sátira, a paródia, a farsa..., desde os anos 70, começaram a invadir a nossa literatura. Bom sinal: grandes mudanças à vista...

Vale lembrar que Chapeuzinho vermelho, de Charles Perrault, foi o livro mais parafraseado da literatura infantil, havendo interpretações políticas, sociais, éticas, psicológicas, sexuais, religiosas etc: Chapeuzinho vermelho (Irmãos Grimm); Chapeuzinho vermelho de raiva (Mário Prata); Chapeuzinho vermelho foi namorar (Ana Cláudia Pelegrinelli); Fita verde no cabelo: nova velha estória (Guimarães Rosa); além, é claro, da versão de Chico Buarque, Chapeuzinho amarelo.

No livro de Chico Buarque, a expressão "Era a Chapeuzinho Amarelo" assinala o começo do novo conto e faz alusão direta à fórmula "Era uma vez". Existe, no entanto, uma diferença: a abertura do texto não aponta mais para algum fato que talvez tenha acontecido uma certa vez, mas evidencia uma história de uma determinada menina e como era seu jeito de ser. De fato, a narrativa traz a história de uma outra Chapeuzinho que nada fazia com medo das consequencias.

A leitura de Chapeuzinho amarelo nos permite interpretar que a menina já tinha ouvido falar de um lobo "que nunca se via, que morava lá longe, do outro lado da montanha, num buraco da Alemanha". Chico Buarque, ao dizer que "Chapeuzinho Amarelo, de tanto pensar no LOBO, de tanto sonhar com o LOBO, de tanto esperar o LOBO, um dia topou com ele" pode estar dando a entender que a menina leu ("um dia se topou com ele") o conto Chapeuzinho vermelho.

Ainda, ao definir o lobo como o "medo mais que medonho" da menina, Chico Buarque deixa claro a intertextualidade com Chapeuzinho vermelho ao repetir o lobo, ainda que fruto da imaginação, como o vilão da história. Tal como o velho lobo, este novo também era capaz de não só comer a vovozinha, mas também "um caçador, rei, princesa, sete panelas de arroz e um chapéu de sobremesa". Essa enumeração faz referências aos contos de fadas tradicionais, citando personagens primordiais que aparecem nesse gênero. 


\section{Considerações Finais}

O estudo crítico do livro Chapeuzinho amarelo, paráfrase do conto Chapeuzinho vermelho, nos permite concluir, assim como em todos os processos histórico-dialéticos, que devemos encarar o novo como consequencia do antigo para não corrermos o risco de fecharmo-nos em ignorância. Contudo, ressalva-se que cada texto deve ser interpretado como produto intencional de um autor que, por sua vez, também é fruto de determinado tempo e espaço. Somente assim poderemos visualizar a literatura como um fenômeno efêmero, provocador do pensamento.

E o livro de Chico Buarque desemboca justamente nessa questão: Chapeuzinho amarelo provoca a imaginação do pequeno leitor, estimula o questionamento dos porquês da existência dos seus medos, instiga o lúdico num jogo de palavras, sons e imagens, ensina a transformar o velho em novo num processo constante de renovação. E são essas possibilidades, inatas a uma literatura infantil de caráter artístico-humanístico, que fomentam um encanto invisível que desperta o gosto da criança pela leitura.

Pertinente dizer que Chapeuzinho amarelo, entendendo a leitura como prática social e não somente como prática escolar, é um livro que forma o gosto pela leitura, sendo destituído, como alguns livros utilitário-pedagógicos, de mensagens específicas como "seja um bom menino" ou "ajude a mamãe e a professora", considerando, assim, a leitura como ato libertário-transformador e prazeroso.

Salienta-se, ainda, que o livro de Chico Buarque, assim como o conto tradicional, trabalha num plano metafórico, permitindo as mais diversas interpretações. Assim, o presente estudo, que chega ao término, não foi mais que uma dessas interpretações que buscou, por meio de um olhar crítico, relacionar algumas das condicionantes que influenciaram (entendese) a produção de Chapeuzinho amarelo.

Em suma, Chapeuzinho amarelo, de Chico Buarque, publicado pela Berlendis \& Vertecchia Editores Ltda em 1979, com ilustrações de Donatella Berlendis, pode ser considerado um livro de literatura infantil "altamente recomendável" para a formação humana dos pequenos leitores.

\section{Referências Bibliográficas}

ARIÈS, P. História social da infância e da família. Rio de Janeiro: Zahar, 1978.

Interface da Educ.

Paranaíba

v. 1

n. 1

p. $95-110$

2010 
BELINKY, Tatiana. Chapeuzinho vermelho. 2. ed. São Paulo: Paulus, 1995. (Tradução da versão dos Irmãos Grimm).

BORDINI, Maria da Glória. A literatura infantil nos anos 80. In: SERRA, Elizabeth D'Angelo (Org.). 30 anos de literatura para crianças e jovens: algumas leituras. Campinas, SP: Mercado de Letras: Associação de Leitura do Brasil, 1998.

BUARQUE, Chico. Chapeuzinho amarelo. 13. ed. São Paulo: Berlendis \& Vertecchia Editores Ltda, 1994.

COELHO, Nelly Novaes. Dicionário crítico da literatura infantil e juvenil brasileira. 4. ed. São Paulo: Editora da Universidade de São Paulo, 1995.

CUNHA, Maria Antonieta Antunes. Literatura infantil: teoria e prática. 18. ed. São Paulo: Atica, 2003.

SANDRONI, Laura. De Lobato à década de 1970. In: SERRA, Elizabeth D'Angelo (Org.). 30 anos de literatura para crianças e jovens: algumas leituras. Campinas, SP: Mercado de Letras: Associação de Leitura do Brasil, 1998.

ZILBERMAN, R. A literatura infantil na escola. São Paulo: Global, 2003. 